\title{
Discovery-Inquiry Meningkatkan Hasil Belajar Muatan Pelajaran IPA
}

\section{W. Gylank Okka Prathama ${ }^{1 *}$, I Made Citra Wibawa ${ }^{2}$, I Kadek Agus Sudiandika ${ }^{3}$}

1,2 Universitas Pendidikan Ganesha, Singaraja, Indonesia

${ }^{3}$ Sekolah Dasar Negeri 3 Temukus, Singaraja, Indonesia

\section{A R T I C L E IN F O}

\section{Article history:}

Received June 26, 2021

Revised June 30, 2021

Accepted July 14, 2021

Available online July 25, 2021

Kata Kunci:

Hasil Belajar, Discovery-Inquiry, IPA

Keywords:

Learning Outcomes, Discovery-

Inquiry, Natural Science

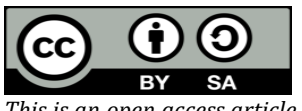

This is an open access article under the CC BY-SA license.

Copyright (C) 2021 by Author. Published by Universitas Pendidikan Ganesha.

\begin{abstract}
A B S T R A K
Pembelajaran kurang menggunakan model inovatif yang menyebabkan hasil belajar muatan pelajaran IPA siswa kelas $\mathrm{V}$ sekolah dasar dibawah kriteria ketuntasan minimal, untuk memperbaiki hal tersebut diadakan penelitian yang bertujuan untuk meningkatkan hasil belajar muatan pelajaran IPA siswa kelas V dengan menerapkan model Discovery-Inquiry. Jenis penelitian ini adalah penelitian tindakan kelas yang terdiri dari dua siklus. Subjek penelitian pada siswa kelas V terdiri dari 21 siswa dengan rincian 13 siswa laki-laki dan 8 siswa perempuan. Metode pengumpulan data yang digunakan yakni dengan tes pilihan ganda diberikan kepada siswa, sedangkan metode analisis data yakni analisis kuantitatif dengan menghitung mean, daya serap, dan ketuntasan belajar siswa tiap siklus. Hasil Analisis data dalam penelitian ini menyatakan rerata hasil belajar pada prasiklus sebesar 67,19 , siklus I sebesar 70,95, dan siklus II 81,14. Secara berurut dari prasiklus ke siklus I, prasiklus ke siklus II, dan siklus I ke siklus II terjadi peningkatan sebesar 3,37 poin, 13,95 poin dan 10,19 poin. Terjadi peningkatan juga pada daya serap siswa dari prasiklus, siklus I, dan siklus II, yaitu 67,19\%; 70,95\%; 81,14\%. Demikian pula terdapat peningkatan persentase siswa yang nilai hasil belajarnya memenuhi KKM dari prasiklus, siklus I, dan siklus II, yaitu 38,09\%; 57,14\%, dan 85,71\%, Jadi model pembelajaran discovery-inquiry dapat meningkatkan hasil belajar muatan pelajaran IPA siswa Sekolah Dasar.
\end{abstract}

\section{A B S T R A C T}

Learning does not use innovative models which causes the learning outcomes of science content for fifth grade elementary school students to be below the minimum completeness criteria, to improve this, a research is conducted that aims to improve the learning outcomes of science content for fifth grade students by applying the Discovery-Inquiry model. This type of research is classroom action research which consists of two cycles. Research subjects in class $V$ students consisted of 21 students with details of 13 male students and 8 female students. The data collection method used is the multiple choice test given to students, while the data analysis method is quantitative analysis by calculating the mean, absorption, and student learning completeness in each cycle. Results Analysis of the data in this study stated the average learning outcomes in the pre-cycle was 67.19, the first cycle was 70.95, and the second cycle was 81.14. Sequentially from precycle to cycle I, precycle to cycle II, and cycle I to cycle II, there was an increase of 3.37 points, 13.95 points and 10.19 points. There was also an increase in the absorption of students from pre-cycle, cycle I, and cycle II, namely $67.19 \% ; 70.95 \% ; 81.14 \%$. Similarly, there is an increase in the percentage of students whose learning outcomes meet the KKM from pre-cycle, first cycle, and second cycle, namely 38.09\%; 57.14\%, and $85.71 \%$, so the discovery-inquiry learning model can improve the learning outcomes of elementary school students' science content.

\section{PENDAHULUAN}

IPA merupakan mata pelajaran yang mempelajarai isi alam semesta beserta fenomena yang terjadi. IPA di SD sesuai dengan karakteristik dan kemampuan siswa serta pengalaman belajar secara langsung diberikan dalam kegiatan pembelajaran, dengan mempelajari IPA sesuai langkah-langkah kegiatan dan melakukan pengujian sesuatu hal yang biasa dilakukan oleh orang lain untuk membuktikan suatu teori sesuai dengan prosedurnya siswa dapat melatih keterampilan, penguasaan konsep (Pebriana et al., 2017; Setyowati et al., 2018). IPA adalah ilmu pengetahuan yang tersusun secara sistematis yang di dalamnya mempelajari mengenai gejala-gejala alam yang lahir dan berkembang melalui suatu metode ilmiah seperti observasi dan eksperimen, dimana kegiatan ilmiah tersebut menuntut sikap ilmiah seperti sikap jujur dan rasa ingin tahu (Purwanti et al., 2020). IPA merupakan hasil dari interpretasi mengenai alam semesta. IPA meliputi cara berpikir, sikap serta langkah-langkah kegiatan scientis untuk mendapatkan produk-produk IPA. Sebagai metode dalam pelaksanaanya IPA terdiri dari kegiatan: observasi, pengukuran, merumuskan, menguji hipotesis, mengumpulkan data, bereksperimen dan 
prediksi (Tembang et al., 2019; Hasrudin \& Asrul, 2020; Sari et al., 2020). Berdasarkan pemaparan mengenai IPA dapat disimpulkan bahwa IPA merupakan ilmu yang mempelajari alam semesta beserta fenomena yang terjadi dengan metode ilmiah untuk memperoleh produk dan pemaham konsep. Pentingnya pembelajaran IPA menuntut peran guru dalam proses pembelajaran serta guru di harapkan mampu memilih dan memilah metode maupun model pembelajaran yang baik dan tepat sehingga proses pembelajaran dapat berjalan dengan efektif dan berhasil dengan baik (Defian, 2019). Guru lebih mengarahkan kemampuan siswa untuk menghafal informasi, sehingga siswa kurang melatih diri menggunakan daya nalarnya. Kegiatan belajar yang seperti ini dapat memberikan dampak yang buruk bagi perkembangan kognitif siswa. Hal ini disebabkan karena siswa tidak diberikan kesempatan untuk membangun dan membentuk pengetahuannya sendiri melalui serangkaian proses ilmiah. Guru masih menggunakan cara mengajar yang bersifat monoton, yaitu dengan menyampaikan materi melalui ceramah. Kenyataan di lapangan menunjukkan guru kurang peka dalam memilih metode yang memberikan ruang kepada siswa untuk terlibat secara aktif dan memahami materi pelajaran yang diajarakan. Guru kurang menggunakan model pembelajaran yang bervariasi dalam kegiatan pembelajaran IPA sehingga hal tersebut berdampak terhadap siswa yang jenuh dan kurang aktif dalam menyimak materi IPA yang disampaikan. Padahal model pembelajaran yang tepat digunakan dapat meningkatkan prestasi belajar peserta didiknya. Proses pembelajaran belum terdapat variasi dalam penerapan model, sehingga siswa beranggapan bahwa belajar IPA sangat membosankan dan menyebabkan siswa kurang tertarik pada pembelajaran IPA (Paramita et al., 2020; Hurit \& Wati, 2020; Suratman, 2018; Hatuti, 2019). Berdasarkan pemaparan mengenai permasalahan dalam pembelajaran IPA dapat disimpulkan bahwa kurangnya penerapan model pembelajaran yang bervariasi menyebabkan berbagai permasalahan dalam pembelajaran IPA.

Masalah yang ditemui setelah melakukan observasi ke sekolah dasar yaitu rendahnya nilai harian pada mata pelajaran IPA kelas $V$ yang diperoleh siswa. Nilai yang di peroleh oleh beberapa siswa masih belum memenuhi kriteria ketuntasan minimum. Hasilnya dapat dilihat dari hasil Penilaian Akhir Semester dengan rerata nilai yang di peroleh siswa SD Negeri 1 Selat kelas V adalah 67 dari KKM yang ditentukan 70. Rerata nilai yang didapat masih kurang untuk mencapai ketuntasan belajar siswa pada muatan pelajaran IPA. Hasil belajar IPA yang rendah, salah satu penyebabnya adalah lemahnya proses pembelajaran yang berlangsung. Indikator keberhasilan belajar adalah hasil belajar, keberhasilan proses pelaksanaan kegiatan pembelajaran yang artinya sebagai akhir atau evaluasi dari proses pembelajaran yang dilakukan dalam bentuk menjawab tes dengan memproleh hasil yang baik (Lepini et al., 2021). Hasil belajar IPA merupakan perubahan kemampuan siswa yang didapat melalui proses pendidikan yang menyangkut aspek kognitif, afektif dan psikomotor setelah melalui proses latihan dalam kegiatan pembelajaran IPA (Sahiu \& Wijaya, 2017). Hasil belajar sering kali digunakan sebagai ukuran untuk mengetahui seberapa jauh seseorang menguasai bahan yang telah diajarkan. Hasil belajar adalah pencapaian bentuk perubahan perilaku yang cenderung menetap dari ranah kognitif, afektif, dan psikomotorik dari proses belajar yang dilakukan dalam waktu tertentu (Kristianto, 2019; Purwani et al., 2018; Fitrianingtyas \& Radia, 2017; Hutauruk \& Simbolon, 2018). Berdasarkan pemaparan mengenai hasil belajar IPA, dapat disimpulkan bahwa hasil belajar IPA adalah perubahan kemampuan berupa aspek kognitif, afektif, dan osikomotor melalui pembelajaran IPA yang cenderung tetap.

Solusi yang diberikan untuk memecahkan permasalahan guna meningkatkan hasil belajar IPA siswa yakni dengan menerapkan model pembelajaran yang sesuai maka pembelajaran di kelas akan menjadi hidup. Proses pembelajaran tidak lagi akan berpusat kepada guru akan tetapi menjadi berpusat kepada siswa. Salah satu model yang mampu membuat pembelajaran berpusat kepada siswa yaitu model pembelajaran discovery-Inquiry. Discovery-inquiry memiliki konsep pembelajaran yang rangkaian kegiatan belajar menekankan pada proses berpikir kritis dan analitis untuk mencari dan menemukan jawaban dari suatu masalah yang di pertanyakan. Ini akan menciptakan keaktifan sebab dalam sintaks yang diterapkan, siswalah yang aktif menggali pengetahuannya (Anitah, 2013; Suherman \& Susanti, 2020). Selain itu, kemampuan bertanya jawab dapat dilatih dengan model discovery-inquiry dan dapat pendapat orang lain saling dihargai saat kegiatan berdiskusi kelompok. Discovery-Inquiry merupakan model pembelajaran esensial dalam melaksanakan proses pembelajaran IPA. Terpusat pada peserta didik adalah model discovery-Inquiry. Selain itu, model discovery Inquiry salah satu fokus yang diutamakan adalah pada pemecahan masalah, serta model ini kemampuan peserta didik diasah seluruhnya untuk belajar dalam situasi proses berfikir, agar peserta didik dapat meyelesaikan masalah yang dituntut secara mandiri dan percaya diri dan pemecahan masalah dapat teratasi (Anitah, 2013). Model pembelajaran discovery-inquiry ini beracuan kepada pembelajaran yang mengarah student centered, yakni siswa lebih diberdayakan, termotivasi, dan berguna pada pengembangan potensi serta kreatifitas siswa. Model pembelajaran discovery-inquiry ini diharapkan mampu menyederhanakan miskonsepsi yang terjadi pada siswa dan 
meningkatkan prestasi belajar siswa (Suryawan et al., 2020). Discovery-inquiry menekankan kepada siswa untuk dapat berpikir kritis, sehingga siswa mampu berperan aktif selama kegiatan pembelajaran.

Beberapa penelitian yang sudah dilakukan menunjukkan bahwa model discovery merupakan model yang jika dibandingkan dengan model penelitian mempunyai pengaruh paling besar terhadap hasil belajar siswa pada pembelajaran IPA khususnya materi tumbuhan dan bagian-bagiannya (Wulandari \& Mustadi, 2019). Model discovery juga merupakan model yang memiliki pengaruh paling besar terhadap hasil belajar siswa dibandingkan dengan model penelitian (Ardianti et al., 2014). Selain itu terdapat pengaruh yang positif dan signifikan antara kecerdasan intelektual dengan hasil belajar siswa. Juga hubungan antara kecerdasan intelektual dengan hasil belajar terhadap prestasi belajar siswa (Sukma \& Sutarni, 2018). Oleh karena itu, tentunya segala keadaan mempengaruhi proses belajarnya. Artinya belajar tidak berdiri sendiri terlepas dari faktor-faktor lain (Novianti et al., 2020). Semakin besar kebiasaan belajar siswa maka semakin besar pula hasil belajar yang dicapai siswa tersebut. Sebaliknya, semakin rendah kebiasaan belajar siswa, maka semakin rendah pula hasil belajar yang dicapainya (Annisa \& Fitria, 2020). Berdasarkan hal tersebut, maka diadakan penelitian yang bertujuan untuk meningkatkan Hasil Belajar Muatan Pelajaran IPA Siswa kelas V SD Negeri 1 Selat Tahun Pelajaran 2020/2021 dengan menerapkan Model Pembelajaran Discovery-Inquiry.

\section{METODE}

Penelitian ini merupakan jenis penelitian tindakan kelas. Temasuk ke dalam jenis penelitian tindakan (action research) yakni penelitian tindakan kelas (PTK) yang dilaksanakan oleh pihak guru, pihak guru berperan secara langsung sebagai seorang peneliti di kelasnya sendiri, ataupun dapat berkolaborasi dengan pihak lain dalam merancang, melaksanakan dan merefleksi tindakan kolaboratif (peneliti berperan sebagai guru sedangkan guru mitra sebagai observer). Diterapkan oleh guru penelitian tindakan kelas adalah kegiatan ilmiah memiliki tujuan untuk memecahkan persoalan yang dialami berhubungan dengan proses pembelajaran sehingga dapat diperbaiki atau dibenahi. Sebanyak dua siklus penelitian tindakan kelas dapat dilaksanakan.

Tiap-tiap siklus penelitian tindakan kelas (PTK) memiliki tahapan, terdiri dari tahapan perencanaan, pelaksanaan, observasi (Djajadi, 2019). Analisis data yang diperoleh menggunakan observasi dan juga tes, dimana untuk teknik analisis data perolehan hasil belajar siswa dianalisis dengan menghitung nilai rerata serta menentukan yang berguna dalam mendeskripsikan hasil belajarnya dan refleksi (Maaruf et al., 2017; Pebrianti et al., 2018; Gonzaga \& Kase, 2020; Indriani et al., 2018). Jadi penelitian tindakan kelas terdiri dari empat tahapan. Subjek dalam penelitian tindakan kelas ini adalah siswa kelas V SD Negeri 1 Selat tahun pelajaran 2020/2021 yang berjumlah 21 orang siswa, terdiri dari 13 siswa laki-laki dan 8 siswa perempuan. Dengan latar belakang kemampuan akademik yang berbedabeda. Objek dalam penelitian ini adalah peningkatan hasil belajar IPA siswa melalui Penerapan Model Discovery-Inquiry pada Siswa Kelas V SD Negeri 1 Selat Tahun Pelajaran 2020/2021. Tempat penelitian dilakukan di SD Negeri 1 Selat yang terletak di Kecamatan Sukasada, Kabupaten Buleleng. Waktu penelitian yang digunakan selama 6 bulan yaitu dari bulan Januari sampai dengan bulan Juni 2021.

Penelitian tindakan kelas menggunakan dua siklus dalam satu siklusnya terdapat empat kegiatan yakni; perencanaan, pelaksanaan, pengamatan, dan refleksi (Fauzan et al., 2017) Adapun bagan deskripsi siklus penelitian tindakan kelas ini disajikan pada gambar 1. Gambar 1, memaparkan bahwa setiap siklus dalam penelitian ini dilaksanakan sebanyak tiga kali pertemuan, dan pada akhir siklus dilaksanakan posttest. Kegiatan pada siklus I yaitu; merancang perangkat pembelajaran dengan sistem pembelajaran daring menggunakan aplikasi WhatsApp dengan menerapkan model pembelajaran discovery-inquiry, selanjutnya pelaksanaan pembelajaran dengan menggunakan perangkat yang sudah dibuat pada tahap perencanaan, pada tahap pelaksanaan langsung diadakan pengamatan berupa kegiatan mencatat semua peristiwa yang terjadi saat pembelajaran, dan yang terakhir tahap refleksi dilakukan evaluasi hasil dari kegiatan yang telah dilaksanakan untuk perencanaan siklus selanjutnya. Karena kegiatan disiklus I kurang maksimal maka dilanjutkan dengan melaksanakan kegiatan siklus II dengan kegiatan: perencanaan berupa menyiapkan perangkat pembelajaran dengan menerapkan model pembelajaran discovery-inquiry dengan menggunakan sistem pembelajaran luring yaitu pertemuan tatap muka terbatas, pelaksanaan pembelajaran dengan menggunakan perangkat yang sudah dibuat pada tahap perencanaan, pengamatan dengan mencatat semua peristiwa yang terjadi saat pembelajaran dan yang terakhir adalah refleksi, pada tahap refleksi dilaksanakan evaluasi hasil dari kegiatan yang telah dilaksanakan untuk perencanaan siklus selanjutnya bila diperlukan. 


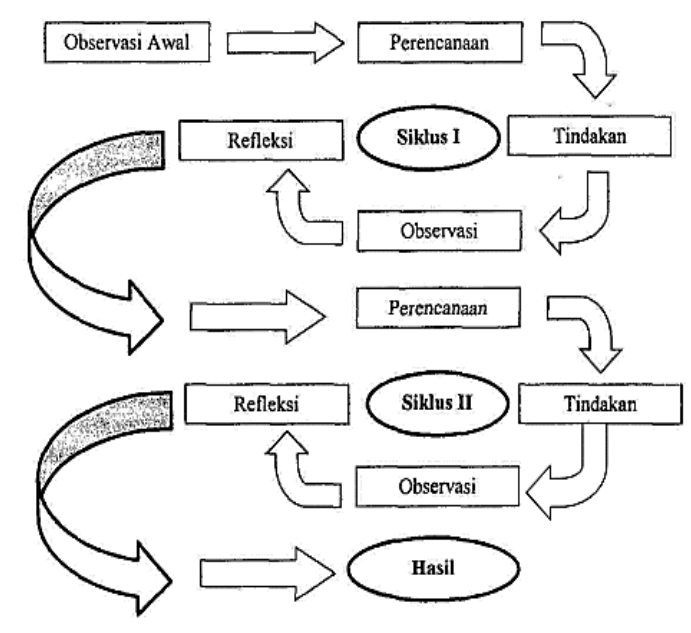

Gambar 1. Bagan Siklus Penelitian Tindakan Kelas (Aqib \& Chotibuddin, 2018)

Dalam penelitian ini, untuk kepentingan mengumpulkan data digunakan beberapa instrumen, antara lain: lembar observasi berisi catatan yang menggambarkan aktivitas peneliti dan siswa dalam kegiatan pembelajaran yang dilakukan di kelas. Observasi kegiatan siswa ini dilaksanakan dengan menggunakan lembar observasi seperti yang untuk mengamati proses pembelajaran yang dilakukan oleh pendidik (Hasan, 2019), selanjutnya dokumentasi proses pembelajaran dan lembar evaluasi berupa soal pilihan ganda sebagai tolak ukur kompetensi siswa terhadap materi IPA yang telah dipelajari dengan menerapkan model pembelajaran discovery-inquiry. Setelah pembuatan kisi-kisi, kegiatan selanjutnya adalah pembuatan soal dan penelitian ini menggunakan tenik analsisi data sebagaiberikut: Langkah pertama, nilai rata-rata tes formatif yang dianalsisi dengan deskriptif kuantitatif yaitu dengan mencari rata-rata nilai hasil belajar siswa setalah menjawab tes formatif setiap siklus, langkah ke dua daya serap klasikal, daya serap siswa klasikal digunakan untuk dapat memperoleh keadaan siswa terkait pemahanan siswa terhadap muatan pelajaran IPA melalui data hasil jawaban dari tes setiap siklus yang dikerjakan oleh siswa dan yang terakhir yakni ketuntasan belajar siswa diperoleh dari nilai siswa yang 70. 4) Penilaian Acuan Patokan (PAP), untuk dapat menentukan keberhasilan belajar siswa berdasarkan patokan atau kriteria tertentu digunakanlah suatu acuan yakni PAP (Penilaian Acuan Patokan). 70 adalah nilai minimal pada penelitian ini untuk perolehan ketuntasan hasil belajar pada muatan IPA. Pedoman yang dipergunakan sesuai dengan PAP skala lima sesuai tabel 2. Berhasilnya suatu penelitian tindakan kelas apabila terdapat peningkatan hasil belajar selama proses pembelajaran berlangsung. Acuan sebagai suatu keberhasilan penelitian yakni memiliki indikator pencapaian. Berikut ini dipaparkan indikator pencapaian yakni mean 75 , daya serap $75 \%$, dan ketuntasan belajar $80 \%$

\section{HASIL DAN PEMBAHASAN}

Ketuntasan dari penilaian tes hasil belajar IPA siswa pada pra siklus menunjukkan nilai rata-rata kelas yaitu 67,19, daya serap 67,19\% dan ketuntasan belajar 38,14\%. Dengan siswa yang tuntas yaitu sebanyak 8 siswa dari 21 jumlah siswa. Jadi, Hasil belajar muatan IPA tergolong rendah dah dibawah kriteria ketuntasan minimal, kemudian diadakan perbaikan dengan penerapan model discovery-Inquiry. Setelah diadakan siklus I dengan model discovery- Inquiry diperoleh menunjukkan peningkatan nilai ratarata kelas yaitu 70,95, daya serap 70,95\% dan ketuntasan belajar yaitu 57,14\% dengan siswa yang tuntas yaitu sebanyak 12 siswa dari 21 jumlah siswa. Dengan hasil demikian masih kurang dari ketentuan indikator keberhasilan, karena siswa kurang aktif dalam pembelajaran sehingga nilai yang diperoleh siswa masih banyak yang belum mencapai KKM yaitu 70. Kemudian dilaksanakan perbaikan pada siklus II siswa mulai terbiasa menggunakan pembelajaran discovery-inquiry sehingga hasil belajar siswa meningkat, hasil belajar IPA siklus II dengan model discovery-inquiry terlihat dari kenaikan nilai rata-rata kelas pada siklus II yaitu 81,14 yang sudah mencapai KKM, daya serap yang diperoleh yaitu 81,14\%, dan ketuntasan belajar yaitu sebesar 85,71\%. Dengan siswa yang tuntas yaitu 18 siswa dari 21 jumlah siswa kelas V SD Negeri 1 Selat dan sudah memenuhi kriteria indikator keberhasilan dari penelitian ini. Peningkatan hasil belajar dari siklus I dan Siklus II secara rinci dapat dipaparkan pada gambar histogram berikut ini. 


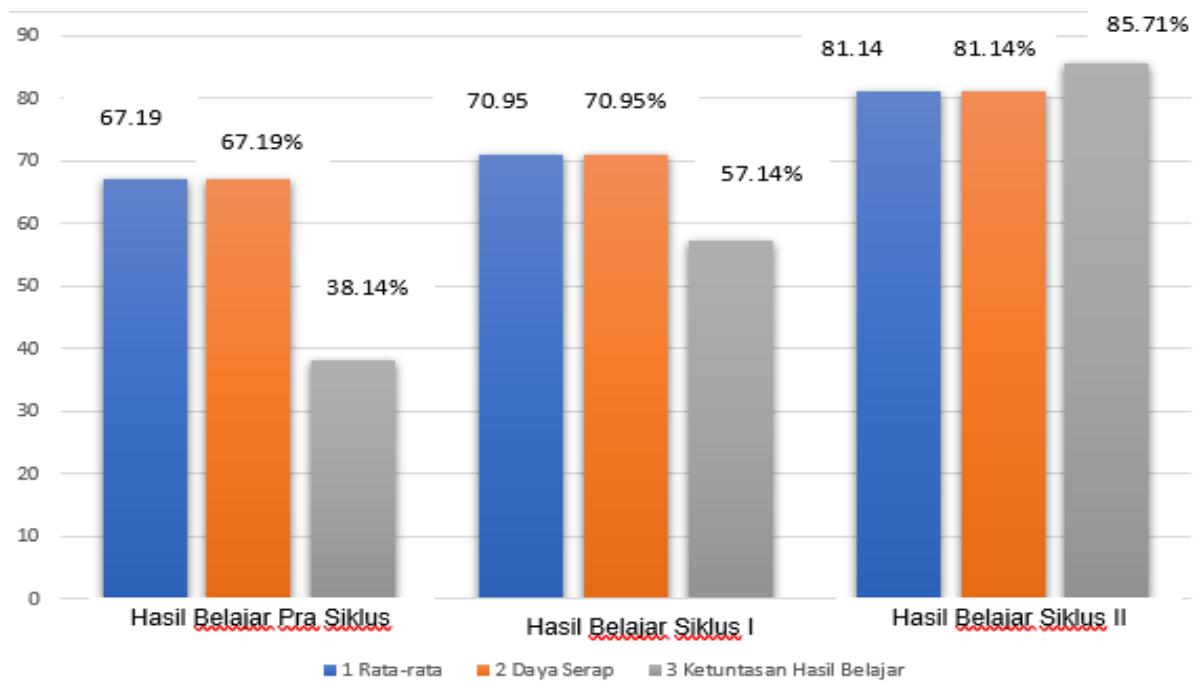

Gambar 2. Peningkatan Hasil Belajar IPA Siswa Prasiklus, Siklus I, dan Siklus II Dengan Model DiscoveryInquiry

Secara rinci dipaparkan pada gambar histogram bahwa hasil belajar siswa dari pra siklus dengan rata-rata kelas yaitu 67,19 , daya serap $67,19 \%$ dan ketuntasan belajar $38,14 \%$, selanjutnya pada siklus I peningkatan nilai rata-rata kelas yaitu 70,95 , daya serap $70,95 \%$ dan ketuntasan belajar yaitu $57,14 \%$ dan terjadi peningkatan pada siklus II yaitu 81,14 yang sudah mencapai KKM, daya serap yang diperoleh yaitu $81,14 \%$, dan ketuntasan belajar yaitu sebesar $85,71 \%$ dan sudah memenuhi kriteria indikator keberhasilan dari penelitian ini. Peningkatan hasil belajar IPA melalui model discovery-inquiry dalam penelitian ini karena dengan adanya langkah-langkah model discovery-inquiry yang berkaitan dengan hakikat pembelajaran IPA dan lebih bermakna dan menyenangkan apabila dilaksanakan dengan berbagai kegiatan inovatif (Budiasa \& Gading, 2020). Hakikat IPA sebagai proses yakni terdapat dalam tahap model discovery-inquiry sebagai berikut: Tahap awal terlebih dahulu memberikan siswa stimulus dengan menyampaikan beberapa pertanyaan terkait konten materi untuk menjadi acuan siswa dalam membuat persoalan sendiri. Memberikan stimulus pada awal sintaks dapat mendekatkan siswa kepada permasalahan terhadap opik yang akan dipelajari, siswa telah terangsang ingin menggali lebih banyak (Nabila, 2019). Kemudian pada tahap ke dua adalah identifikasi masalah, siswa kesempatan kepada peserta didik untuk mengidentifikasi berbagai persoalan yang ada dalam konten materi pembelajaran IPA. Hakikat IPA sebagai sikap ilmiah diterapkan dalam kegiatan. Model discovery- Inquiry langkahlangkahnya guru memiliki peran sebagai pemberi permasalahan selanjutnya mengajak siswa untuk memecahkan beragam permasalahan melalui kegiatan sebagai berikut; pengamatan, percobaan atau prosedur penelitian. Hanyalah sebagai narasumber tugasnya guru memberikan bantuan jika diperlukan untuk pencegah suatu kegagalan dalam memecahkan masalah (Nurizka et al., 2016). Bentuk pembelajaran discovery-inquiry adalah memberikan motivasi kepada siswa dalam penyelidikan masalah dengan menggunakan tata cara dan keterampilan ilmiah karena membantu siswa melatih kemampuan penemuan. Menyelidiki beberapa informasi serta dapat melakukan penemuan solusi dari suatu masalah dan melatih mereka untuk mengembangkan fakta, membangun konsep, dan menggambarkan kesimpulan umum atau teori yang menjelaskan fenomena yang dihadapinya (Nurdin et al., 2019).

Tahap mengumpulkan informasi, kesempatan diberikan kepada siswa untuk menggali secara lebih luas beragam persoalan yang telah dibuat berdasarkan pemahaman dari konten tersebut, melalui pengumpulan berbagai informasi yang relevan dengan cara membaca literatur baik secara online maupun offline, mengamati obyek, wawancara dengan narasumber atau melakukan uji coba sendiri dan lain-lain oleh peserta didik. Siswa belajar melalui penemuan sendiri, koordinasi, dan memperoleh simpulan dari pemahamannya terkait muatan IPA sehingga pengetahuan tersimpan lebih lama (Bahari et al., 2018). Tidak bisa dilaksanakan dengan cara menghafal kegiatan pembelajaran IPA di SD atau dapat disebut pasif hanya mendengarkan guru menjelaskan konsep, namun siswa sendiri yang harus melaksankan beragam sikap ilmiah; melalui percobaan, pengamatan maupun bereksperimen secara aktif yang akhirnya terbentuk kesadaran kreativitas untuk menjaga dan memperbaiki fenomena maupun gejala alam yang terjadi untuk selanjutnya terbentuk sikap ilmiah yang memiliki daya guna untuk menjaga kestabilan alam ini secara baik dan lestari (Sulthon, 2016). Model pembelajaran yang sesuai untuk mengaktifkan siswa 
dan diharapkan dapat mengurangi miskonsepsi IPA adalah model pembelajaran discovery-inquiry (Tompo et al., 2016). Pada tahapan ke empat, yakni kegiatan pengolahan informasi/data yang dilaksanakan siswa secara kelompok ataupun mandiri melakukan pengolahan, pengacakan, pengklasifikasian, pentabulasian bahkan penghitungan data pada tingkat kepercayaan tertentu. IPA sebagai ilmu pengetahuan dapat diverifikasi dengan tahapan ke lima yakni verifikasi hasil, dalam langkah ini guru mengarahkan peserta didik untuk melakukan pembuktian dari hipotesis atau pernyataan yang telah dirumuskan berdasarkan hasil pengolahan informasi yang telah ada. IPA memiliki pengertian sebagai pengetahuan didapatkan melalui beberapa cara yakni; pengumpulan data dengan eksperimen, pengamatan, dan deduksi untuk menghasilkan suatu kejelasan tentang sebuah fenomena gejala yang dapat diyakini (Widiastuti, 2018). Setelah itu mempresentasikan di depan pendidik dan peserta didik yang lain untuk mendapat masukan pada tahap terakhir generalisasi, siswa dapat menarik kesimpulan atau generalisasi tertentu berdasarkan hasil verifikasi dan masukan dari guru maupun siswa lainnya.

Selanjutnya, peningkatan hasil belajar siswa melalui model discovery-inquiry didukung oleh hasil penelitian ahli yakni pembelajaran yang memungkinkan siswa untuk menggunakan semua potensi baik kognitif, efektif, dan psikomotor adalah terdapat pada discovery-inquiry (Wartono et al., 2018). Model pembelajaran discovery-inquiry baik untuk diimplementasikan pada pendidikan anak usia dini, karena pada dasarnya anak adalah pembelajar yang mempunyai rasa ingin tahu yang besar dan mampu mengkonstruksi pengetahuannya sendiri. Selain itu, anak pada usia 2-6 tahun berada pada tahap praoprasional, sehingga perkembangan mentalnya sudah muncul, sehingga pembelajaran akan lebih bermakna (Wartini et al., 2017). Terdapat peningkatan setiap siklus, siklus pertama mengalami peningkatan sedang dengan hasil belajar siswa rata-rata 53,34\% atau 16 siswa belum memperoleh peningkatan kemampuan. Pada siklus kedua jumlah siswa yang bermasalah sebanyak $16,67 \%$ atau berkurang 5 siswa SDN 2 Way Halim permai Bandar Lampung tercapai dengan baik sehingga hasil proses belajar siswa mengalami peningkatan yang signifikan (Harianto \& Agung, 2020). Selanjutnya, Hasil penelitian analisis data post test menunjukkan bahwa rerata kompetensi pengetahuan IPA kelompok eksperimen lebih tinggi daripada rerata kelompok kontrol $(0,60>0,40)$. Berdasarkan hasil analisis uji-t diperoleh t_hitung sebesar 5,405 dan t_tabel dengan $\mathrm{dk}=26+44-2=68$ pada taraf signifikansi 5\% adalah 2,000 karena t_hitung > t_tabel $(5,405>2,000)$, maka H0 ditolak. Hal ini membuktikan bahwa terdapat pengaruh yang signifikan kompetensi pengetahuan IPA kelompok siswa yang dibelajarkan melalui model pembelajaran discovery-inquiry berbasis portofolio dengan siswa yang dibelajarkan melalui pembelajaran konvensional (Restyani et al., 2018). Perbedaan penelitian terdahulu dengan penelitian yang telah dilaksanakan adalah penelitian terdahulu diadakan di jenjang pendidikan kanak-kanak dan ada yang dilaksanakan di kelas V SD, namun dilaksanakan dengan jenis penelitian eksperimen.

Adanya peningkatan hasil belajaran muatan IPA melalui penerapan model discovery- inquiry berkostribusi pada perbaikan belajar IPA siswa sehingga pembelajaran IPA siswa sekolah dasar lebih inovatif dan yang sesuai dengan hakikat belajar IPA sebagai konsep, prosedur, dan sikap ilmiah, selain itu guru sekolah dasar saat menggunakan model pembelajaran dapat melatih keterampilan sebagai fasilitator. Implikasi ari adanya penelitian tindakan kelas ini adalah dalam kegiatan pembelajaran IPA secara daring dapat menggunakan model pembelajaran discovery-inquiry sehingga walaupun belajar di rumah siswa dapat melatih kemandirian belajarnya dengan metode yang ilmiah. Keterbatasan penelitian ini adalah belum berbantuan media pembelajaran dan kendala kegiatan pembelajaran ini saat melaksanakan pengumpulan data hasil belajar siswa karena keterbatasan jaringan. Solusi yang diberikan kepada penelitian lain yang sejenis dengan penelitan ini adalah dapat dipadukan dengan penggunaan media pembelajaran dan mempersiapkan pengumpulan data dengan maksimal.

\section{SIMPULAN}

Berdasarkan hasil penelitian dan pembahasan dapat disimpulkan bahwa model pembelajaran discovery-inquiry dapat meningkatkan hasil belajar muatan IPA SD. Berdasarkan terjadinya peningkatan hasil belajar, model pembelajaran discovery-inquiry diharapkan mampu diterapkan pada pelajaran lain selain pelajaran IPA untuk peningkatan hasil belajar siswa.

\section{DAFTAR PUSTAKA}

Anitah, S. (2013). Strategi Pembelajaran. Biosel: Biology Science and Education, 2(2), 120. https://doi.org/10.33477/bs.v2i2.376.

Annisa, D. S., \& Fitria, Y. (2020). Hubungan kebiasaan belajar dengan hasil belajar ipa siswa sekolah dasar. $\begin{array}{lllll}\text { Journal of Basic Education } & \text { Studies., } & 4(2), & 498-508 .\end{array}$ https://ejurnalunsam.id/index.php/jbes/article/view/3211. 
Aqib, Z., \& Chotibuddin, M. (2018). Teori dan Aplikasi Penelitian Tindakan Kelas: Untuk Guru/Kepala dan Pengawas Sekolah/Dosen dan Mahasiswa/Peneliti. Rineka Cipta.

Ardianti, S. D., Prasetyo, A. P. B., \& Susanti, R. (2014). Developing A Thematic Inquiry-Discovery Module on Metabolism For Junior Student. International Conference on Mathematics, Science, and Education, 2014(Icmse), 1-5.

Bahari, N. K. I., Darsana, I. W., \& Putra, D. K. N. S. (2018). Pengaruh Model Discovery Learning Berbantuan Media Lingkungan Alam Sekitar terhadap Hasil Belajar IPA. Jurnal Ilmiah Sekolah Dasar, 2(2), 103. https: //doi.org/10.23887/jisd.v2i2.15488.

Budiasa, P., \& Gading, I. K. (2020). Model Pembelajaran Inkuiri Terbimbing Berbantuan Media Gambar Terhadap Keaktifan dan Hasil Belajar IPA. Mimbar PGSD Undiksha, 8(2), 253-263. https: //doi.org/10.23887/jjpgsd.v8i2.26526.

Defian, S. D. (2019). Pengaruh Model Quantum Teaching Terhadap Hasil Belajar Siswa Pada Tema Daerah Tempat Tinggalku Kelas IV SD N 05 Kuala Tahun Pembelajaran 2018/2019. Jurnal Ilmiah Aquinas, 2(2), 22-43. https://doi.org/http://dx.doi.org/10.1234/jia.v2i2.551.

Djajadi, M. (2019). Pengantar Penelitian Tindakan Kelas (Classroom Action Research). Bumi Intaran.

Fauzan, M., Gani, A., \& Syukri, M. (2017). Penerapan Model Problem Based Learning Pada Pembelajaran Materi Sistem Tata Surya Untuk Meningkatkan Hasil Belajar Siswa. Jurnal Pendidikan Sains Indonesia (Indonesian Journal of Science Education), 5(1), 27-35. http://jurnal.unsyiah.ac.id/JPSI/article/view/8404.

Gonzaga, M. F., \& Kase, E. B. S. (2020). Pengaruh Penelitian Tindakan Kelas Terhadap Prestasi Belajar Peserta Didik di SDK ST. Yoseph 3 Naikoten Kupang Tahun Ajaran 2019/2020. Jurnal Selidik (Jurnal Seputar Penelitian Pendidikan Keagamaan), 1(2), 58-68. https: //ejurnal.org/index.php/selidik/article/view/10.

Gosa, M. N., \& Ade, J. (2020). Meningkatkan Aktivitas dan Hasil Belajar Matematika Dengan Strategi Pembelajaran Problem Based Learning Materi Segitiga dan Segiempat. Jimat, 1(1), 42-50. https://jurnal.stkipkieraha.ac.id/index.php/jimat/article/view/96.

Harianto, J., \& Agun tps://ejurnal.org/index.php/selidik/article/view/10g, P. (2020). Peningkatan Pembelajaran Pai Melalui Discovery Inquiry Pada Sekolah Dasar Di Bandar Lampung. AlTadzkiyyah: Jurnal Pendidikan Islam, 10(2), 203-217. https: //doi.org/10.24042/atjpi.v10i2.4793.

Hasan, A. (2019). Model Pembelajaran CTL Berbasis IT Untuk Menguasai Mufradar Bahasa Arab. Al-Lisa, 5(2), 133-147. https://journal.iaingorontalo.ac.id/index.php/al/article/view/860.

Hatuti, E. (2019). Penggunaan Media Tiga Dimensi dapat Meningkatkan Hasil Belajar IPA pada Siswa Kelas IVB. Jurnal PGSD, 12(1), 55-62. https://jurnalmahasiswa.unesa.ac.id/index.php/jurnalpenelitian-pgsd/article/view/10650.

Hutauruk, P., \& Simbolon, R. (2018). Meningkatkan Hasil Belajar Siswa Dengan Alat Peraga Mata Pelajaran IPA Kelas IV SDN Nomor 14 Simbolon Purba. SEJ, 8(2), 112. https://doi.org/10.24114/sejpgsd.v8i2.9770.

Lepini, K. N. P., Suarjana, I. M., \& Sudarmawan, G. A. (2021). Penerapan Model Pembelajaran Problem Based Learning Untuk Meningkatkan Hasil Belajar Muatan Pelajaran Ipa Siswa Kelas Iv Sd. Jurnal Penelitian Dan ..., 5(2), 278-286. http://dx.doi.org/10.23887/jppp.v5i2.37427.

Nabila. (2019). Penggunaan Model Pembelajaran Discovery Learning Dalam Peningkatan Hasil Belajaran Siswa Di Sekolah Dasar. Ilmiah Pendidikan Dan Pembelajaran, 18(2), 56. https: //doi.org/10.24036/fip.100.v18i2.318.000-000.

Novianti, C., Sadipun, B., \& Balan, J. M. (2020). Pengaruh Motivasi Belajar terhadap Hasil Belajar Matematika Peserta Didik. Science and Phich Education Jurnal, 3(2). /https://doi.org/10.31539/spej.v3i2.992 PENGARUH.

Nurdin, K., Muh., H. S., \& Muhammad, M. H. (2019). the Implementation of Inquiry-Discovery Learning. IDEAS: Journal on English Language Teaching and Learning, Linguistics and Literature, 7(1), 1-10. https://doi.org/10.24256/ideas.v7i1.734.

Nurizka, A., Sukaryawan, M., \& Lesmini, B. (2016). Pengaruh Model Discovery-Inquiry Terhadap Hasil Belajar Siswa Pada Pembelajaran Kimia Di Kelas X Sma It Raudhatul Ulum, Sakatiga. Jurnal Penelitian Pendidikan Kimia, 3(2), 147-158. https://doi.org/10.36706/jppk.v3i2.8161.

Pebriana, G. R., Dibia, I. K., \& Renda, N. T. (2017). Penerapan Model Pembelajaran Picture and Picture Untuk Meningkatkan Aktivitas dan Hasil Belajar Siswa Kelas V Universitas Pendidikan Ganesa. PGSD Universitas Pendidikan Ganesha, https: //ejournal.undiksha.ac.id/index.php/JJPGSD/article/viewFile/9861/6272.

Purwanti, E., Palupi, R. Z. P., Galuh, A., \& Rianingsih, D. (2020). Pengembangan Instrumen Penilaian Keterampilan Abad 21. CV Kota Tua Jalan Sanan.

Restyani, N. K. N., Wiyasa, K. N., \& Abadi, I. . G. S. (2018). Pengaruh Model Pembelajaran Discovery Inquiry 
Berbasis Portofolio Terhadap Kompetensi Pengetahuan IPA. Jurnal Penelitian Dan Pengembangan Pendidikan, 2(2), 168. https://doi.org/10.23887/jppp.v2i2.15399.

Sahiu, S., \& Wijaya, H. (2017). Hubungan Motivasi Belajar Ekstrinsik Terhadap Hasil Belajar Psikomotorik Pada Mata Pelajaran Agama Kristen Kelas V Di SD Zion Makassar. Jurnal Jaffray, 15(2), 231-248. http://dx.doi.org/10.25278/jj71.v15i2.262.

Sari, R., Jamal, F., \& Nurjannah. (2020). Pengaruh Model Pembelajaran Inkuiri Terhadap Di Sd N Ujong Patihah. 7(2), 12-23. https://ejournal.stkipbbm.ac.id/index.php/pgsd/article/view/526.

Setyowati, E., Kristin, F., \& Anugraheni, I. (2018). Penggunaan Model Pembelajaran Discovery Learning Untuk Meningkatkan Kreativitas Dan Hasil Belajar Siswa Kelas 5 Sd Negeri Mangunsari 07. Justek: Jurnal Sains Dan Teknologi, 1(1), 76. https://doi.org/10.31764/justek.v1i1.408.

Suherman, A., \& Susanti, Y. (2020). Use Of Inquiry Learning Model Type Expository With Type Discovery. Paper Knowledge . Toward a Media History of Documents, 12-26. https://doi.org/10.31980/civicos.v4i1.784.

Sukma, F. M., \& Sutarni, N. (2018). Pengaruh Manajemen Sumber Daya Berbasis Iso 9001:2008 Terhadap Kinerja Guru. Jurnal Pendidikan Manajemen Perkantoran, 3(2), 99. https://doi.org/10.17509/jpm.v3i2.11770.

Sulthon. (2016). Pembelajaran IPA yang Efektif Dan Menyenangkan Bagi Siswa Madrasah Ibtidaiyah (Mi). Elementary, 4(1). https://journal.iainkudus.ac.id/index.php/elementary/article/view/1969.

Suryawan, Wayan, S. I., \& Komang, S. I. (2020). Pengaruh Metode Pembelajaran Discovery-Inquiry Terhadap Reduksi Miskonsepsi dan Prestasi Belajar Fisika. Jurnal Teknologi Pembelajaran Indonesia, $\quad 10(10), \quad 1 . \quad$ https://ejournalpasca.undiksha.ac.id/index.php/jurnal_tp/article/view/3395.

Tompo, B., Ahmad, M. A., \& Muris. (2016). Pengembangan Model Pembelajaran Discovery-Inquiry untuk Mereduksi Miskonsepsi IPA Peserta Didik SMP. Jurnal Sains Dan Pendidikan Fisika, 12(3), 240253. https://doi.org/10.35580/jspf.v12i3.3053.

Wartini, A., Hadi al-asy'ari, M. K., \& Multahada, A. (2017). Menggagas Model Pembelajaran DiscoveryInquiry pada Pendidikan Anak Usia Dini. Intizar, 23(1), 151-164. https://doi.org/10.19109/intizar.v23i1.1614.

Wartono, W., Takaria, J., Batlolona, J. R., Grusche, S., Hudha, M. N., \& Jayanti, Y. M. (2018). InquiryDiscovery Empowering High Order Thinking Skills and Scientific Literacy on Substance Pressure Topic. Jurnal Ilmiah Pendidikan Fisika Al-Biruni, 7(2), 139-151. https://doi.org/10.24042/jipfalbiruni.v7i2.2629.

Widiastuti, N. L. G. K. (2018). Pendidikan IPA SD. In Modul. Dwijendra.

Wulandari, D. G. R., \& Mustadi, A. (2019). Comparison of Discovery and Inquiry Model: Which Model is More Effective in Natural Science (IPA) Learning? International Journal of Educational Research Review, 4, 711-718. https://doi.org/10.24331/ijere.628710. 